\title{
SYSTEM IMPEDANCYJNEJ TOMOGRAFII KOMPUTEROWEJ BAZUJĄCY NA PROCESORZE SYGNALOWYM O NISKIM POBORZE MOCY
}

\author{
Daniel Olchowy \\ Net-Art., ul. Lotnicza 3, 20-322 Lublin \\ Streszczenie. Artykut zawiera opis rozwiazania systemu pomiarowego tomografii impedancyjnej bazujacego na procesorze sygnałowym \\ o niskim poborze mocy. \\ Slowa kluczowe: tomografia impedancyjna, procesor sygnałowy

\section{ELECTRICAL IMPEDANCE TOMOGRAPHY HARDWARE SYSTEM BASED ON LOW POWER DIGITAL SIGNAL PROCESSOR}

Abstract. Article contains description of the measurement system electrical impedance tomography solutions based on digital signal processor with low power consumption.

Keywords: electrical impedance tomography, digital signal processor

\section{Wstęp}

Tomografia impedancja jest stosunkowo nową techniką obrazowania w inżynierii, w której wykorzystuje się właściwości elektryczne materiałów. Dany obiekt pobudzany jest ze źródła prądowego lub napięciowego, a następie obserwuje się powstały na jego brzegu rozkład napięć.

Z matematycznego punktu widzenia impedancyjna tomografia komputerowa należy do zagadnień odwrotnych pola elektromagnetycznego. Zagadnieniem odwrotnym pola elektromagnetycznego nazywamy proces identyfikacji, w którym zmierza się do wyznaczenia parametrów opisujących dane pole, na podstawie posiadania niektórych, wybranych informacji charakterystycznych dla tego pola [1].

Numeryczną analizę problemu przeprowadza się $\mathrm{z}$ wykorzystaniem metody elementów skończonych. Jest to obecnie najbardziej efektywna metoda numeryczna, służąca do przybliżonego rozwiązania zarówno płaskich i przestrzennych zagadnień polowych o skomplikowanej geometrii, w których ośrodek może wykazywać cechy niejednorodności prądów, konduktywności.

Algorytm komputerowej rekonstrukcji obrazu poszukuje iteracyjnie takiego rozkładu konduktywności, dla którego obliczone wartości napięć międzyelektrodowych są możliwie najbliższe odpowiednim wartościom pomiarowym. Wartości początkowe konduktywności w punkcie wyjściowym procesu iteracyjnego są dobierane doświadczalnie, aby otrzymać możliwie najlepszy wynik $[3,4]$.

\section{Koncepcja rozwiązania sprzętowego}

Aby sprostać wymaganiom stawianym przez algorytmy obliczeniowe, istotne jest zastosowanie odpowiedniego rozwiązania sprzętowego. W celu uzyskania odpowiedniej jakości rekonstruowanych obrazów konieczne jest, aby pomiary odbywały się $\mathrm{z}$ odpowiednią dokładnością, precyzją i częstotliwością. Duża ilość danych, jakie system musi przetworzyć, zdecydowała o wyborze układu z procesorem sygnałowym.

Procesor sygnałowy to układ wyspecjalizowany pod kątem przetwarzania i cyfrowej obróbki sygnałów. Charakterystyczną cechą procesorów sygnałowych jest pamięć zrealizowana w zmodyfikowanej architekturze harwardzkiej: rozdzielona wewnętrzna pamięć programu i danych oraz obszerny blok pamięci wspólnej, dający się mapować do dowolnej przestrzeni. Daje to możliwość równoczesnego dostępu do danych oraz odczytu instrukcji wykonywanych przez procesor. Szyna adresowa danych i adresowa dla pamięci zewnętrznych są natomiast wspólne [2].
Dodatkowo w procesorach sygnałowych lista instrukcji procesora zoptymalizowana jest pod kątem operacji przetwarzania sygnałów, w szczególności operacji najczęściej występujących podczas filtracji FIR i IIR oraz przy realizacji transformat Fouriera i kosinusowej. Wszystkie instrukcje procesorów są instrukcjami warunkowymi, co dodatkowo zwiększa ich możliwości oraz redukuje liczbę dodatkowych rozkazów. Ważną cechą, znacznie zwiększającą prędkość działania procesora, jest przetwarzanie potokowe.

Przetwarzanie potokowe polega na rozbiciu każdej instrukcji na kilka części logicznych związanych z różnymi operacjami wykonywanymi przez procesor. Każda $z$ tych części wykonywana jest w innej jednostce logicznej procesora, co umożliwia rozpoczęcie wykonywania kolejnej instrukcji już po wykonaniu pierwszego etapu instrukcji poprzedzającej, a nie dopiero po zakończeniu całej rozkazu, jak to ma miejsce w przypadku przetwarzania szeregowego.

Procesory sygnałowe bardzo często wykorzystywane są do przetwarzana sygnałów w czasie rzeczywistym. Prędkość wykonywania przez procesor operacji powinna być zatem zsynchronizowana $\mathrm{z}$ tempem odbierania $\mathrm{i}$ przesyłania danych. Częstotliwość ta jest zwykle ustalona odgórnie dla danej implementacji i zależy od przyjętej częstotliwością próbkowania w układzie.

\section{Koncepcja komunikacji i przetwarzania danych systemu}

Założenia pracy systemu zdeterminowane zostały przez obszar w którym system powinien działać. Pokrycie obszaru około $80 \mathrm{~m}$ zapewnione jest przez 16 elektrod umieszonych w równomiernie pełniących rolę elektrod pomiarowych oraz 1 elektrodę pełniącą funkcję nadrzędną $\mathrm{w}$ prezentowanym układzie. Cały układ pomiarowy łączy się z serwerem pełniącym funkcję kontroli i monitorowania.

Rozkład elektrod pomiarowych przedstawia poniższy schemat.

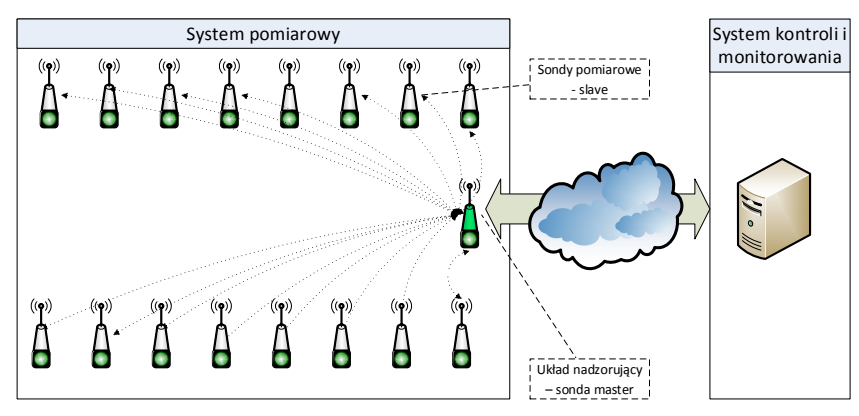

Rys. 1. Schemat komunikacji systemu 
Głównym elementem wchodzącym w skład sondy pomiarowej jest układ RISC, który zarówno w sondzie pomiarowej jak i sondzie nadzorującej odpowiada zarówno za pomiar jak i zapewnienie komunikacji. Komunikacja pomiędzy elementami odbywa się poprzez sieć bezprzewodową realizowaną przez zintegrowany układ na każdej z elektrod.

Wybór architektury RISC jako bazy dla sond pomiarowych systemu podyktowany został przez to aby pobór prądu był minimalny. Ograniczenie poboru energii ma zapewnić ciągłą pracę układu nawet do roku pracy przy zasilaniu bateryjnym. Uśpiony układ potrzebuje mniej energii. Podstawowa idea zastosowania energooszczędnego układu sprowadza się do tego, by jak najdłużej trwać w stanie uśpienia, budzić się o ustalonej $\mathrm{i}$ zaprogramowanej porze $\mathrm{w}$ celu wykonania zadania pomiaru i przesłaniu uzyskanych danych, a $\mathrm{w}$ przypadku sondy nadzorującej do zebrania pomiarów, dokonania obliczeń i ponownego przejścia do stanu uśpienia.

W przypadku sondy nadzorującej głównym jej elementem jest procesor sygnałowy wraz z układem RISC. Dzięki wysokiemu poziomowi integracji sondy nadzorującej $\mathrm{z}$ urządzeniami peryferyjnymi (we/wy, moduł gsm), jak i obniżonemu poziomi rozpraszania ciepła, rozwiązanie pozwala zapewnić wydłużony czas pracy na bateriach $[5,6]$.

Ponieważ układ pomiarowy wymaga precyzyjnej synchronizacji czasowej istotne jest aby poszczególne jego elementy pozwalały na odpowiednie działanie w trybie uśpienia co zapewni zgodność wykonywanych pomiarów. Kolejną istotną cechą układu jest możliwość zmiany w dowolnej chwili źródła sygnału taktującego i możliwość zmiany częstotliwości jego taktowania.

Poza dokonywaniem obliczeń $\mathrm{w}$ oparciu o zebrane przez sondy pomiarowe dane kolejnym istotnym zadaniem sondy master jest także wymuszenie i zebranie informacji o pierwotnym stanie badanego obiektu, zapewnienie diagnostyki układu pomiarowego poprzez test obecności ustalonych elektrod pomiarowych oraz odebranie i wysyłanie do systemu kontroli i monitorowania parametrów dotyczących częstotliwości dokonywania pomiarów oraz uzyskanych wyników przez układ pomiarowy.

System pomiarowy działa w sposób cykliczny. W pierwszym cyklu sonda master sprawdza obecność ustalonych elektrod pomiarowych. Po pozytywnym zweryfikowaniu obecności przesyła żądanie zebrania informacji o środowisku pierwotnym. Po odebraniu z poszczególnych elektrod pierwotnych pomiarowych danych elektroda master wysyła sygnał do rozpoczęcia pomiaru i cyklicznego przełączenia poszczególnych par elektrod.

System, ze względu na pełnione role, obejmuje przede wszystkim:

- źródło o zmiennej częstotliwości,

- multiplekser,

- system akwizycji danych,

- moduł sterujący z procesorem sygnałowym.

\section{Podsumowanie}

Platforma sprzętowa bazująca na procesorach o niskim poborze mocy firmy Texas Instruments TMS320C6742 oraz mikroprocesor rodziny ARM9x pozwalającą bardzo efektywnie wykorzystać przetwarzanie potokowe realizowane w procesorze, które realizowane jest poprzez programowe zrównoleglenie pętli. Elementem większości algorytmów przetwarzania sygnałów są bowiem pętle o dużej liczbie iteracji, które stanowią najbardziej wymagający pod względem potrzebnej mocy obliczeniowej, a co za tym idzie najbardziej czasochłonny element programów. Szczególnie często występują one w filtrach cyfrowych i algorytmach FFT.

Aby przyspieszyć wykonywanie algorytmów i optymalnie wykorzystać możliwości procesora, kompilator wbudowany w środowisko programistyczne także posiada możliwość programowego zrównoleglenia pętli [5].

Wykorzystanie dostępnych zasobów układu ułatwione jest poprzez użycie narzędzi programowych, które dzięki dedykowanemu interfejsowi JTAG umożliwiają podłączenie odpowiedniego emulatora sprzętowego, przystosowanego do współpracy $\mathrm{z}$ procesorami rodziny TMS320 oraz ARM9x a przez to efektywnie jego wykorzystanie.

\section{Literatura}

[1] David S Holder.: Electrical Impedance Tomography Methods, History and Applications, Series in Medical Physics and Biomedical Engineering, London 2005

[2] Hoe Cher Wee.: Development of a Digital Signal Processing measurement platform for Biomedical Magnetic Induction Tomography and Spectroscopy, University of Glamorgan December 2010

[3] Filipowicz S. F., Nita K.: Porównanie wielokanałowych układów pomiarowych w tomografii impedancyjnej, Prace Instytutu Elektrotechniki, zeszyt 230, Warszawa 2007.

[4] Filipowicz S. F., Rymarczyk T.: Tomografia impedancyjna pomiary, konstrukcje i metody tworzenia obrazu, BelStudio, Warszawa 2003.

[5] Texas Instruments Technical Documents TMS320C6742 Fixed/Floating Point Digital Signal Processor (Rev. C), Texas Instruments, 03 Oct 2011.

[6] Texas Instruments Embedded Processors Wiki http://www.processors.wiki.ti.com (ARM MPU Performance, Ultra Low Power DSP).

Mgr inż. Daniel Olchowy

e-mail: daniel.olchowy@gmail.com

Daniel Olchowy ukończył studia magisterskie na Wydziale Elektrotechniki, Automatyki, Informatyki

i Elektroniki Akademii Górniczo-Hutnicze

$\mathrm{w}$ Krakowie oraz studia podyplomowe z rachunkowości zarządczej i controllingu na Wydziale Zarządzania Akademii Górniczo-Hutniczej w Krakowie.

W pracy badawczej, koncentruje się nad zastosowaniem procesorów sygnałowych w przetwarzaniu danych w tomografii impedancyjnej.

otrzymano/received: 27.06 .2013 przyjęto do druku/accepted: 21.09.2013

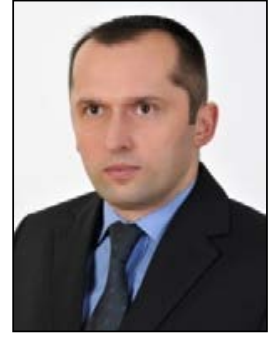

